\title{
IMPLEMENTASI MODEL PEMBELAJARAN PREDICT-OBSERVE- EXPLAIN (POE) DALAM MENINGKATKAN KEMAMPUAN PENALARAN MATEMATIS SISWA SEKOLAH DASAR
}

\author{
Nina Nuraeni, Dede Salim Nahdi, Ujiati Cahyaningsih \\ Universitas Majalengka \\ ninanuraeni@gmail.com
}

\begin{abstract}
This research is motivated by the lack of mathematical reasoning abilities of fifth grade students at SDN Anggrawati I. This research is a classroom action research conducted collaboratively by teachers and researchers. The action research was carried out in two cycles, each cycle consisting of two actions. The subjects of this study were Grade V students of SDN Anggrawati 1, as many as 19 students consisting of 13 male students and 6 female students. Data collection tools used in data collection are tests in the form of mathematical reasoning ability test sheets, observation sheets in the form of student activity observation sheets and teacher performance observations sheets and documentation in the form of learning activities. The data obtained in the form of test results, observation results and documentation. The data analysis technique used is quantitative descriptive analysis to analyze the final test results of each cycle and qualitative descriptive analysis for the results of observations of each cycle. The results showed that the implementation of learning by applying the Predict-Observe-Explain (POE) learning model can improve the mathematical reasoning ability of Grade V students of SDraw Anggrawati I. This is indicated by an increase from before giving action to the second cycle. So it can be concluded that the application of the Predict-Observe-Explain (POE) learning model can improve the mathematical reasoning ability of fifth grade students at SDN Anggrawati I.
\end{abstract}

Keywords: Mathematical reasoning ability, Predict-Observe-Explain (POE) learning model

\section{ABSTRAK}

Penelitian ini dilatarbelakangi oleh kurangnya kemampuan penalaran matematis siswa kelas V SDN Anggrawati I. Penelitian ini merupakan penelitian tindakan kelas yang dilaksanakan secara kolaboratif oleh guru dan peneliti. Tindakan penelitian dilaksanakan dalam dua siklus, masing-masing siklus terdiri dari dua tindakan. Subjek penelitian ini adalah siswa kelas V SDN Anggrawati 1, sebanyak 19 orang siswa terdiri dari 13 siswa laki-laki dan 6 siswa perempuan. Alat pengumpul data yang digunakan dalam pengumpulan data adalah tes berupa lembar soal tes kemampuan penalaran matematis, lembar observasi berupa lembar observasi kegiatan siswa dan lembar observasi kinerja guru serta dokumentasi berupa foto kegiatan pelaksanaan pembelajaran. Data yang diperoleh berupa hasil tes, hasil observasi dan dokumentasi. Teknik analisis data yang digunakan adalah analisis deskriptif kuantitatif untuk menganalisis hasil tes akhir setiap siklus dan analisis deskriptif kualitatif untuk hasil observasi setiap siklus. Hasil penelitian menunjukkan bahwa pelaksanaan pembelajaran dengan penerapan model pembelajaran Predict-ObserveExplain (POE) dapat meningkatkan kemampuan penalaran matematis siswa kelas V SDN Anggrawati I. Hal ini ditunjukan dengan adanya peningkatan dari sebelum pemberian tindakan hingga siklus II. Maka dengan demikian dapat disimpulkan bahwa penerapan model pembelajaran Predict-Observe-Explain (POE) dapat meningkatkan kemampuan penalaran matematis siswa kelas V di SDN Anggrawati I.

Kata Kunci: Kemampuan penalaran matematis, model pembelajaran Predict-Observe-Explain (POE).

\section{Pendahuluan}

Matematika merupakan salah satu mata pelajaran yang memiliki kedudukan yang penting bagi perkembangan ilmu pengetahuan dan teknologi. Menurut Sugiarto (dalam Nahdi, 2017: 7) matematika merupakan ilmu universal yang mendasari perkembangan teknologi modern, mempunyai peran penting dalam berbagai disiplin dan memajukan daya pikir manusia. Adapun 
menurut Nahdi (2018: 51) matematika merupakan mata pelajaran yang memiliki peran sangat penting dalam kehidupan sehari-hari. Mengingat begitu pentingnya matematika maka mata pelajaran ini menjadi salah satu ilmu dasar sebagai mata pelajaran yang wajib diajarkan mulai tingkat pendidikan dasar sampai perguruan tinggi.

Berdasarkan Permendiknas no 22 tahun 2006 :Kemampuan bernalar merupakan salah satu dari sekian kecerdasan yang sangat penting dimiliki, dikuasai dan dikembangkan ketika akan mempelajari matematika, terlebih saat siswa dihadapkan pada masalah matematika yang harus diselesaikannya.

Kemampuan penalaran sangatlah diperlukan dalam mata pelajaran matematika karena orang yang memiliki kemampuan penalaran yang tinggi serta mampu mengkomunikasikan ide atau gagasan matematikanya dengan baik cenderung mempunyai pemahaman yang baik terhadap konsep yang dipelajari serta mampu memecahkan permasalahan yang berkaitan dengan konsep yang dipelajari yang nantinya akan berpengaruh pada prestasi belajar siswa. Depdiknas menyatakan bahwa "Materi matematika dan penalaran matematika merupakan dua hal yang tidak dapat dipisahkan, yaitu materi matematika dipahami melalui penalaran dan penalaran dipahami dan dilatihkan melalui belajar matematika."

Upaya mendorong siswa untuk meningkatkan kemampuan penalaran matematis menjadi salah satu hal yang harus diperhatikan sebagai aspek penting kecakapan hidup dan sebagai bekal dalam menghadapi tuntutan di masa yang akan datang. Dengan kata lain, bila siswa dilatih untuk melakukan penalaran matematis maka siswa akan mampu mengelola dan mengambil keputusan untuk menyelesaikan suatu masalah sebab siswa telah dilatih menjadi terampil bagaimana mengambil keputusan disertai dengan alasan atau bukti yang berasal dari informasi yang relevan yang telah diperoleh dan menyimpulkan solusi dari suatu masalah yang diberikan.

Upaya untuk melatih siswa dalam melakukan penalaran matematis dapat dilakukan dengan meminta mereka untuk menganalisis data yang telah diperoleh sehingga mereka dapat menemukan hubungan antar variabel atau dapat menjelaskan tentang data berdasarkan teori yang ada, menguji hipotesis yang telah diajukan dan membuat kesimpulan. Menurut Sani (2014:70), ada beberapa strategi yang dapat dilakukan yaitu sebagai berikut:

a. Melatih siswa mengidentifikasi pola dari sekelompok data yang telah diperoleh. Pola yang mungkin ditemukan adalah pola angka, pola gambar, pola kejadian dan sebagainya.

b. Melatih siswa untuk menentukan data yang relevan dengan yang tidak relevan, dan data yang dapat diverifikasi dan yang tidak dapat diverifikasi.

c. Melatih siswa membandingkan atau membedakan dua kelompok data atau dua grafik dari percobaan yang sejenis.

d. Melatih siswa untuk mencari hubungan antara dua data yang saling terkait.

e. Melatih siswa untuk melakukan interpretasi berdasarkan data yang telah diperoleh

f. Melatih siswa untuk dapat memberikan argument yang utuh terhadap temuan atau data yang diperoleh sesuai dengan permasalahan yang dikaji.

g. Melatih siswa untuk menganalisis, mensisntesis, mengevalusai, membuat generalisasi dan menarik kesimpulan

h. Melatih siswa untuk dapat memberikan solusi atau menetapkan beberapa penyelesaian alternative yang dapat dilakukan untuk menyelesaikan suatu permasalahan. 
Siswa dikatakan mampu melakukan penalaran matematis bila ia mampu menggunakan penalaran sesuai dengan indikator-indikator penalaran matematis yang telah ditentukan para ahli. Peraturan Dirjen Dikdasmen Depdiknas Nomor 506/C/Kep/PP/2004 tanggal 11 November 2004 tentang rapor diuraikan bahwa indikator siswa yang memiliki kemampuan dalam penalaran matematika adalah:

a. Mengajukan dugaan.

b. Melakukan manipulasi matematika.

c. Menarik kesimpulan, menyusun bukti, memberikan alasan atau bukti terhadap kebenaran solusi.

d. Menarik kesimpulan dari pernyataan.

e. Memeriksa kesahihan suatu argumen.

f. Menemukan pola atau sifat dari gejala matematis untuk membuat generalisasi.

Menurut Sumarmo (Ramdani, 2012:46) mengungkap bahwa indikator siswa menguasai kemampuan penalaran matematis adalah sebagai berikut :

a. Menarik kesimpulan logis.

b. Memberi penjelasan menggunakan gambar, fakta, sifat, hubungan yang ada.

c. Memperkirakan jawaban dan proses solusi.

d. Menggunakan pola hubungan untuk menganalisis, membuat analaogi, generalisasi, dan menyusun serta menguji konjektur.

e. Mengajukan lawan contoh.

f. Mengajukan aturan inferensi, memeriksa validitas argument dan menyusun argument yang valid.

g. Menyusun pembuktian langsung, pembuktian tak langsung dan pembuktian dengan induksi matematika.

Indikator yang digunakan dalam penelitian ini menggunakan dua indikator yang di ungkapkan Sumarmo (Ramdani, 2012:46) yaitu:

a. Memberi penjelasan menggunakan gambar, fakta, sifat, hubungan yang ada.

b. Menggunakan pola hubungan untuk menganalisis, membuat analogi, generalisasi, dan menyusun serta menguji konjektur.

Pemilihan indikator ini berdasarkan pertimbangan kesesuaian dengan karakteristik dari siswa, karakteristik materi dan tingkat perkembangan siswa. Karakteristik siswa kelas tinggi khususnya V SD umumnya merupakan usia dimana keterampilan motorik dan kognitifnya berkembang dengan baik oleh karena itu guru harus bisa mengoptimalkan, mengembangkan dan memperhatikan dengan baik agar siswa dapat berkembang secara maksimal.

Penalaran matematis dapat melatih siswa dalam proses berpikir untuk menghubungkan faktafakta atau data-data, mengindentifikasi pola yang dikaji, memberikan argumen sesuai dengan permasalahan yang dikaji, menganalisis dan menginterpretasi berdasarkan data yang diperoleh secara sistematis menuju suatu kesimpulan sesuai dengan permasalahan yang dikaji serta memberikan solusi untuk menyelesaikan suatu permasalahan. Dengan demikian siswa merasa suatu permasalahan dapat dipahami, dipikirkan, dibuktikan, dan dapat dievaluasi.

Penalaran merupakan salah satu bentuk kemampuan kognitif. Selama ini dalam pelaksanaan pembelajaran guru jarang menyentuh dan menjadikan penalaran sebagai tujuan pembelajaran, 
sehingga hal tersebut mengakibatkan masih rendahnya kemampuan penalaran siswa. Hal ini sejalan dengan pendapat Nahdi (2015: 15) yang menyatakan kemampuan penalaran matematis siswa memang tidak dibiasakan untuk dikembangkan sejak sekolah dasar sehingga tampak dengan jelas ketika siswa beranjak ke tingkat menengah kemampuan kemampuan penalaran matematis menjadi masalah terhadap siswa itu sendiri. Hal ini akan menjadi sebuah kekhawatiran yang sangat besar jika kemampuan tersebut tidak dikembangkan sejak sekolah dasar.

Hasil observasi yang dilakukan oleh peneliti di SDN Anggrawati I selama ini aktivitas pembelajaran siswa kelas $\mathrm{V}$ kurang, khususnya dalam kemampuan penalaran matematis. Pembelajaran yang didominasi oleh guru belum memberikan kesempatan kepada siswa untuk mengungkapkan gagasannya sehingga siswa cenderung pasif. Siswa kelas V yang berjumlah 19 siswa sebenarnya sangat efektif bila diterapkan model pembelajaran yang bervariatif dalam pembelajaran matematika sehingga siswa tidak merasa jenuh.

Hasil tes pada siswa kelas V SDN Anggrawati I pada kegiatan tes awal untuk mengukur kemampuan penalaran matematis yang dilakukan oleh peneliti, menunjukan bahwa hasil tes yang dicapai siswa masih tergolong rendah. Tes kemampuan penalaran matematis yang diberikan mengacu pada indikator kemampuan penalaran matematis yaitu memberi penjelasan menggunakan gambar, fakta, sifat, hubungan yang ada, menggunakan pola hubungan untuk menganalisis, membuat analogi, generalisasi, dan menyusun serta menguji konjektur. Dari keseluruhan siswa kelas V yang berjumlah 19 siswa dengan kriteria ketuntasan minimal (KKM) 75. Siswa yang telah tuntas dan telah memenuhi KKM sebanyak 6 orang (31,57\%) dan jumlah siswa yang belum tuntas dan mendapat nilai di bawah KKM adalah 13 orang (68,42\%). Sebanyak 6 orang memperoleh nilai tertinggi yaitu 75 dan 4 orang memperoleh nilai terendah yaitu 60. Selain itu ketika melakukan tanya jawab dengan guru, sebagian besar siswa masih ragu dan malu-malu dalam mengungkapkan gagasannya.

Berdasarkan permasalahan diperlukan perbaikan dalam upaya peningkatan mutu pembelajaran, salah satunya dengan menerapkan model pembelajaran yang inovatif. Model pembelajaran yang inovatif serta yang dapat meningkatkan kemampuan penalaran matematis siswa salah satunya yaitu model pembelajaran Predict-Observe-Explain (POE), dimana model ini merupakan model pembelajaran yang dapat menciptakan suasana kelas menjadi lebih menyenangkan dan siswa akan lebih bersemangat dalam belajar serta dapat mengembangkan kemampuan penalaran matematis siswa. Seperti yang dikemukakan Warsono dan Hariyanto (2012:93), yang mengatakan bahwa model POE dilandasi oleh teori pembelajaran kontruktivisme yang beranggapan bahwa melalui kegiatan prediksi, observasi dan menerangkan sesuatu hasil pengamatan maka struktur kognitifnya akan terbentuk dengan baik.

Sesuai dengan pernyataan tersebut maka model Predict-Observe-Explain (POE) ini membantu siswa dalam memperoleh informasi, menggali ide, dan kemampuan berfikir serta membantu mengembangkan kemampuan penalaran siswa dengan melakukan prediksi dan observasi. Lapono (2010:25) menyatakan, "Teori konstruktivisme dalam pembelajaran didasari oleh kenyataan bahwa setiap individu memiliki kemampuan untuk mengkonstruksi kembali pengalaman atau pengetahuan yang dimilikinya." Berdasarkan pendapat tersebut, maka siswa sendiri yang harus menemukan pengetahuan atau konsep, menemukan segala sesuatu untuk dirinya, dan berusaha dengan ide-idenya. Hubungan model Predict-Observe-Explain (POE) dengan 
teori kontruktivisme menganggap bahwa siswa dengan pengetahuan yang telah mereka miliki akan dapat mengembangkan kemampuan atau pengetahuannya itu. Dengan menerapkan model PredictObserve-Explain (POE) di kelas, diharapkan mampu menjadi solusi yang tepat untuk mengatasi rendahnya kemampuan penalaran matematis siswa di kelas V SDN Anggrawati 1 kecamatan Maja Kabupaten Majalengka.

\section{Metode Penelitian}

Metode yang digunakan dalam penelitian ini adalah Penelitian Tindakan Kelas. Menurut Sanjaya (2009:1), "Penelitian Tindakan Kelas adalah salah satu teknik agar pembelajaran yang dikelola guru selalu mengalami peningkatan melalui perbaikan secara terus menerus." Sehingga penelitian ini diharapkan mampu memecahkan masalah yang mucul di kelas.

Berdasarkan jenis penelitian yang dipilih, desain penelitian yang digunakan berbentuk siklus yang mengacu pada model yang dikembangkan John Elliot. Menurut Kusumah dan Dwitagama (Novianti, 2013:54) mengungkapkan bahwa, "Desain PTK John Elliot dilaksanakan dalam satu siklus yang terdiri dari beberapa tindakan, yaitu tindakan satu, tindakan dua dan tindakan tiga." Dalam setiap tindakan meliputi kegiatan, perencanaan, pelaksanaan, observasi dan refleksi.

Penelitian ini menggunakan dua siklus, yang terdiri dari dua tindakan. Pemilihan model PTK John Elliot dengan dua siklus yang terdiri dari dua tindakan ini didasarkan pada pemikiran bahwa didalam mata pelajaran terdiri dari beberapa pokok bahasan dan setiap pokok bahasan terdiri dari beberapa materi yang tidak dapat diselesaikan dalam satu kali tindakan. Pelaksanaan satu tindakan merupakan satu kali pertemuan. Dalam setiap tindakan terdiri atas perencanaan, pelaksanaan, observasi dan refleksi.

Subjek penelitian ini adalah siswa kelas V SDN Anggrawati 1 Kecamatan Maja Kabupaten Majalengka, dengan jumlah seluruhnya 19 siswa yang terdiri dari 13 siswa laki-laki dan 6 siswa perempuan. Objek dari penelitian ini adalah peningkatan kemampuan penalaran matematis siswa kelas V di SDN Anggrawati 1. Adapun instrumen yang digunakan untuk mengumpulkan data yaitu soal tes uraian, untuk mengukur kemampuan penelaran matematis siswa, dan dan lembar observasi, untuk mengamati pelaksanaan pembelajaran matematika dengan menggunakan model POE.

\section{Hasil dan Pembahasan}

1. Tingkat kemampuan penalaran matematis siswa

Penalaran matematis adalah penalaran mengenai objek matematika. Objek matematika dalam hal ini adalah cabang-cabang matematika yang dipelajari. Maka dengan demikian penalaran merupakan proses berfikir yang abstrak, logis dan sistematis dalam menarik sebuah kesimpulan. Pengolahan informasi membutuhkan kemampuan logika (ilmu menalar). Kemampuan berfikir tingkat atas ini tentu akan berkaitan erat dengan perkembangan intelektual siswa dalam meningkatkan kemampuan penalaran matematika.

Seorang guru perlu memahami kemampuan berpikir siswa sehingga tidak memaksakan materi-materi pelajaran yang tingkat kesukarannya tidak sesuai dengan kemampuan siswa. Apabila hal ini terjadi maka siswa mengalami kesukaran untuk mencerna gagasan-gagasan dari materi 
pelajaran yang diberikan, maka usaha guru untuk membelajarkan siswa bisa disebut gagal. Disini penting bahwa setiap siswa memiliki kemampuan penalaran matematis.

Berdasarkan hasil penelitian, hasil tes belajar siswa mengalami peningkatan. Hal ini dapat dilihat dari gambaran lengkap berkaitan dengan tes hasil belajar siswa selama kegiatan pembelajaran dalam penelitian yang peneliti laksanakan dapat dilihat pada tabel sebagai berikut:

Tabel 1

Hasil tes siswa

\begin{tabular}{|c|c|c|c|}
\hline \multicolumn{2}{|c|}{ Siklus I } & \multicolumn{2}{c|}{ Siklus II } \\
\hline T1 & T2 & T1 & T2 \\
\hline $57,89 \%$ & $63,15 \%$ & $78,94 \%$ & $84,21 \%$ \\
\hline
\end{tabular}

Dari tabel 4.22 dapat kita ketahui bahwa terdapat peningkatan tes siswa dalam proses pembelajaran pada siklus I tindakan I yang semula hasil tes siswa hanya 57,89\% meningkat sebanyak 5,26\% pada tindakan II menjadi 63,15\%. Pada siklus II tindakan I mengalami kenaikan sebanyak 15,79\% dari sikus sebelumnya menjadi 78,94\% kemudian meningkat sebanyak 5,27\% pada tindakan II menjadi 84,21\%/ Hasil penelitian pada siklus II dalam penelitian ini telah mencapai 80\% yaitu sebesar 84,21. Maka dengan demikian peneliti menyimpulkan bahwa penelitian ini telah berhasil.

Gambaran grafik hasil tes siswa dalam proses pembelajaran dapat dilihat pada grafik berikut:

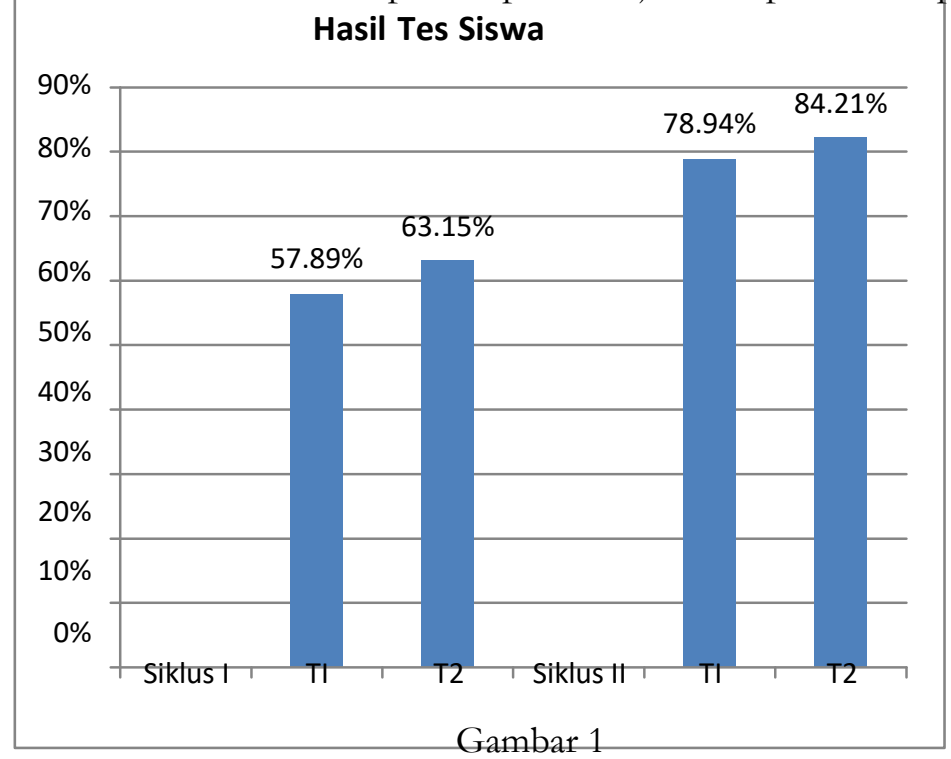

Grafik hasil tes siswa

Berdasarkan data di atas, hasil tes siswa pada setiap siklus dan setiap tindakan mengalami peningkatan. Perolehan hasil siswa pada siklus I tindakan I sebesar 57,89\% meningkat menjadi 63,15\% pada siklus I tindakan II. Sedangkan pada siklus II tindakan II perolehan hasil siswa sebesar 78,94\% menjadi $84,21 \%$ pada siklus II tindakan II. Hal ini membuktikan bahwa tingkat penalaran siswa selama proses pembelajaran telah mengalami peningkatan. 


\section{Penerapan Model Pembelajaran Predict-Observe-Explain (POE)}

Pada model Predict-Observe-Explain (POE) guru berperan sebagai pembimbing dalam kegiatan pembelajaran, pertanyaan, mengeksplorasi pengetahuan siswa, menyediakan fasilitas yang diperlukan siswa dan memberikan dukungan dalam upaya meningkatkan perkembangan intelektual siswa sehingga struktuk kognitif siswa dapat terbentuk dengan baik. Hal ini sejalan dengan Warsono dan Hariyanto yang mengatakan bahwa model POE dilandasi oleh teori pembelajaran kontruktivisme yang beranggapan bahwa melalui kegiatan prediksi, observasi dan menerangkan sesuatu hasil pengamatan maka struktur kognitifnya akan terbentuk dengan baik. Berdasarkan pendapat di atas, model POE diorientasikan untuk mengembangkan kemamampuan belajar siswa dengan cara meminta siswa melaksanakan tiga tugas utama yaitu memprediksi, mengamati dan memberikan penjelasan agar struktuk kognitif siswa dapat terbentuk dengan baik.

Adapun hasil observasi selama proses pembelajaran baik pada kegiatan siswa maupun kinerja guru mengalami peningkatan pada setiap siklus. Untuk lebih jelasnya, peningkatan kegiatan siswa dan kinerja guru dalam pembelajaran dapat dilihat pada tabel berikut ini :

Tabel 2

Hasil observasi kegiatan siswa

\begin{tabular}{|c|c|c|c|}
\hline \multicolumn{2}{|c|}{ Siklus I } & \multicolumn{2}{c|}{ Siklus II } \\
\hline T1 & T2 & T1 & T2 \\
\hline $75 \%$ & $82,14 \%$ & $92,85 \%$ & $96,42 \%$ \\
\hline
\end{tabular}

Berdasarkan tabel 4.23, hasil observasi kegiatan siswa mengalami peningkatan di setiap siklus dan tindakannya. Pada siklus I tindakan I hasil observasi siswa sebesar 75\% naik sebesar 7,14\% pada tindakan II sehingga menjadi 82,14\%. Pada siklus II tindakan I mengalami kenaikan sebanyak 10,71\% dari sikus sebelumnya menjadi $92,85 \%$ dan naik sebesar 3,57\% pada tindakan II sehingga menjadi $96,42 \%$.

Gambaran grafik hasil tes siswa dalam proses pembelajaran dapat dilihat pada grafik berikut: 


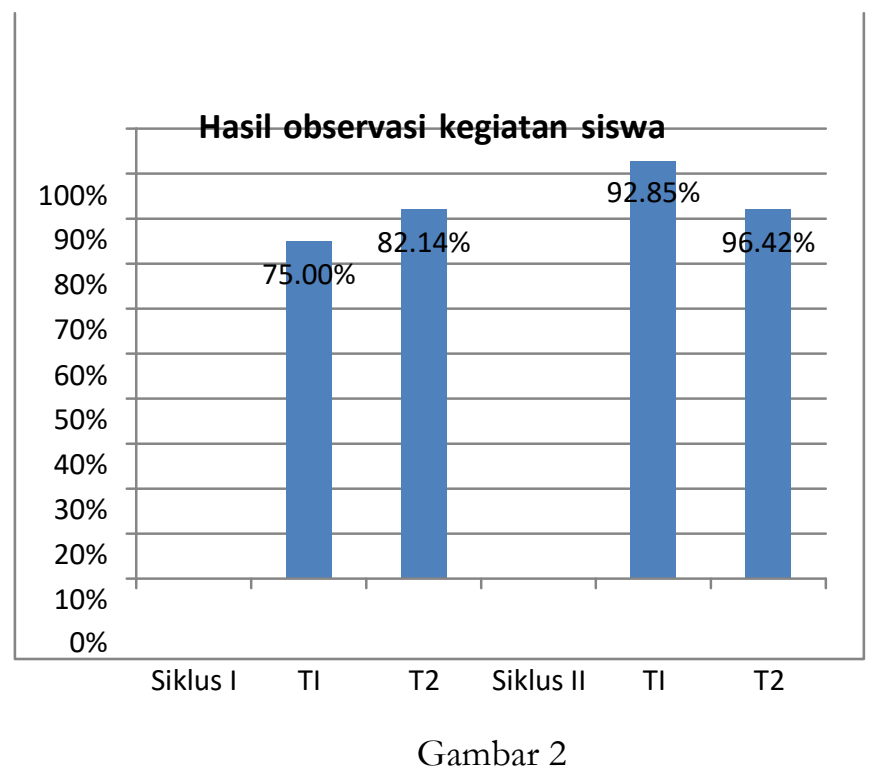

Hasil observasi kegiatan siswa

Berdasarkan data di atas, hasil observasi kegiatan siswa selama proses pembelajaran pjada setiap siklus dan setiap tindakan mengalami peningkatan. Perolehan observasi siswa pada siklus I tindakan I sebesar 75\% meningkat menjadi $82,14 \%$ pada siklus I tindakan II. Sedangkan pada siklus II tindakan II perolehan observasi siswa sebesar 92,85\% menjadi $96,42 \%$ pada siklus II tindakan II.

Pada siklus I penyampaian materi dan upaya guru dalam memancing kemampuan penalaran matematis siswa belum maksimal. Sehingga guru melakukan perbaikan pada tindakan selanjutnya. Pada siklus II guru sudah mengalami peningkatan dalam proses pembelajaran. hanya saja guru perlu memberikan tindak lanjut pada siswa untuk memaksimalkan hasil belajar siswa. Adapun untuk lebih jelasnya peningkatan kinerja guru dalam melakukan pembelajaran dapat dilihat pada tabel berikut ini:

Tabel 3

Hasil observasi kinerja guru

\begin{tabular}{|c|c|c|c|}
\hline \multicolumn{2}{|c|}{ Siklus I } & \multicolumn{2}{c|}{ Siklus II } \\
\hline T1 & T2 & T1 & T2 \\
\hline $75 \%$ & $78,57 \%$ & $89,28 \%$ & $96,42 \%$ \\
\hline
\end{tabular}

Berdasarkan tabel 4.24, hasil observasi kinerja guru mengalami peningkatan di setiap siklus dan tindakannya. Pada siklus I tindakan I hasil observasi kinerja guru sebesar 75\% naik sebesar 3,57\% pada tindakan II sehingga menjadi 78,57\%. Pada siklus II tindakan I mengalami kenaikan sebanyak 3,71\% dari sikus sebelumnya menjadi 89,28\% dan naik sebesar 7,14\% pada tindakan II sehingga menjadi $96,42 \%$. 
Gambaran grafik hasil observasi guru dalam proses pembelajaran dapat dilihat pada grafik berikut:

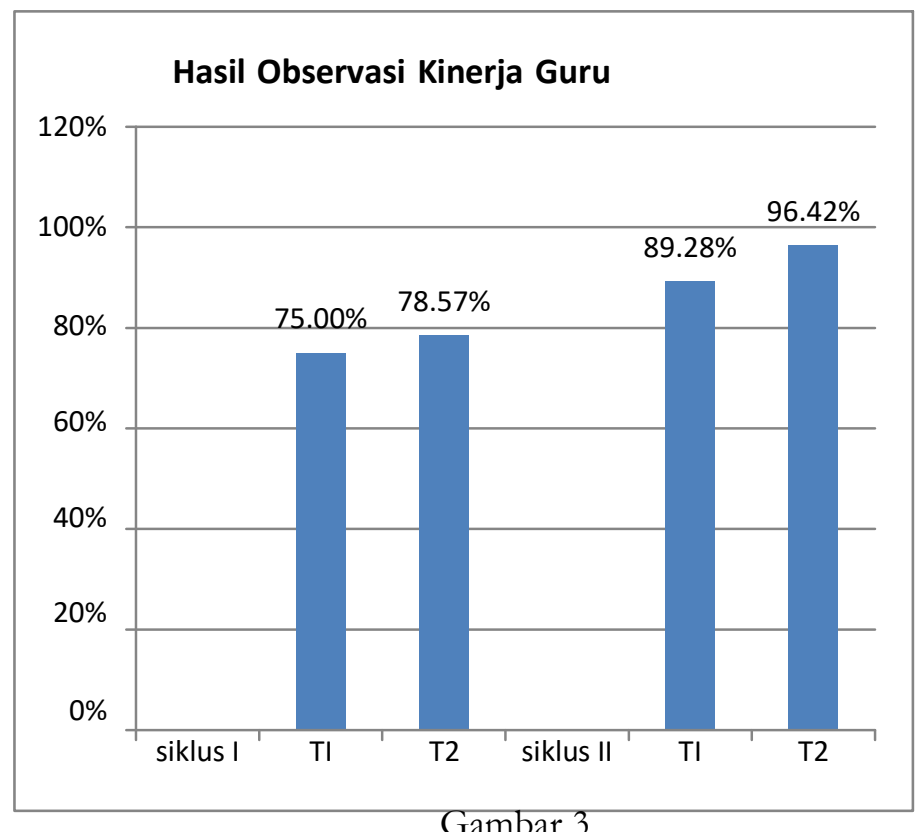

Gambar 3

Grafik hasil observasi kinerja guru

Berdasarkan data di atas, hasil observasi kinerja guru selama proses pembelajaran mengalami peningkatan dalam setiap siklusnya. Perolehan persentase hasil observasi guru pada siklus I tindakan I sebesar 75\% menjadi 78,57\% pada siklus I tindakan II. Sedangkan pada siklus II tindakan I hasil observasi guru semula sebesar 89,28\% mengalami peningkatan pada siklus II tindakan II menjadi 96,42\%.

Adapun hasil observasi siswa selama proses pembelajaran mengalami peningkatan pada setiap siklusnya.

3. Peningkatan Kemampuan Penalaran Matematis Siswa dengan Penerapan Model Pembelajran

Predict-Observe-Explain (POE)

Perkembangan berpikir seorang siswa bergerak dari kegiatan berpikir konkret menuju berpikir abstrak. Seorang guru perlu memahami kemampuan berpikir siswa sehingga tidak memaksakan materi-materi pelajaran yang tingkat kesukarannya tidak sesuai dengan kemampuan siswa. Apabila hal ini terjadi maka siswa mengalami kesukaran untuk mencerna gagasan-gagasan dari materi pelajaran yang diberikan, maka usaha guru untuk membelajarkan siswa bisa disebut gagal. Disini penting bahwa setiap siswa memiliki kemampuan penalaran matematis. Karin Brodie (Shadiq, 2004:5) menyatakan bahwa, "Mathematical reasoning is reasoning about and with the object of mathematics." Pernyataan tersebut dapat diartikan bahwa penalaran matematis adalah penalaran mengenai objek matematika.

Peningkatan kemampuan penalaran matematis siswa dengan penggunaan model Predictobserve-explain (POE) mengalami peningkatan pada setiap siklusnya. Hal ini dilihat dari hasil tes 
belajar siswa selama pembelajaran. Gambaran grafik nilai perbandingan kemampuan penalaran matematis siswa pada data awal, siklus I dan siklus II dapat pula dilihat pada grafik berikut:

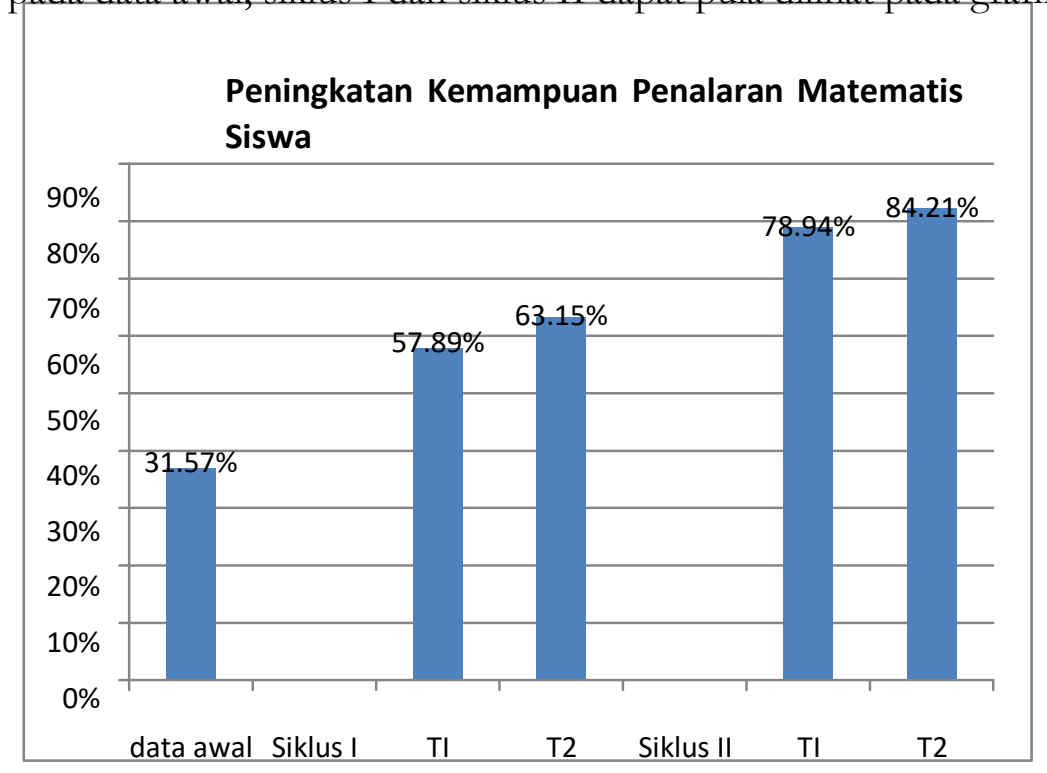

Gambar 4

Grafik peningkatan kemampuan penalaran matematis

Dari data di atas dapat kita ketahui bahwa kemampuan penalaran matematis siswa pada data awal hanya mencapai rata-rata 67,63 dengan persentase ketuntasan 31,57\%. Pada siklus I tindakan I hanya mencapai rata-rata 73,47 dengan persentase ketuntasan belajar sebesar 57,89\%. Pada siklus 1 tindakan II mengalami peningkatan dengan rata-rata 75,10 dengan persentase ketuntasan belajar sebesar 63,15\%. Pada siklus II tindakan I mengalami kenaikan yang cukup signifikan dengan nilai rata-rata 79,47 dan persentase ketuntasan belajar mencapai 78,94\%. Pada akhir siklus yaitu pada siklus II tindakan II terdapat peningkatan kemampuan penalaran matematis siswa hingga mencapai rata -rata 81,15 dengan pencapaian ketuntasan belajar mencapai 84,21\%.

\section{Kesimpulan}

1. Penerapan model pembelajaran Predict-Observe-Explain (POE) berjalan dengan baik dan lancar. Proses pembelajaran baik siswa maupun guru mengalami peningkatan yang cukup signifikan, dimana pembelajaran terlihat lebih kondusif dari sebelumnya, siswa terlibat aktif dalam pembelajaran, siswa sudah terlihat berani dalam mengungkapkan gagasannya serta menjawab dengan jawaban yang bervariasi.

2. Kemampuan penalaran matematis siswa selama proses pembelajaran pada setiap siklusnya mengalami peningkatan.

3. Penerapan model pembelajaran Predict-Observe-Explain (POE) pada materi bangun ruang dapat meningkatkan kemampuan penalaran matematis siswa kelas V di SDN Anggrawati I. 


\section{Daftar Pustaka}

Lapono, Nabisi. (2010). Belajar dan Pembelajaran SD. Jakarta: Direktorat Jenderal Pendidikan Tinggi Departemen Pendidikan Nasional.

Nahdi, D S. (2015). Meningkatkan Kemampuan Berpikir Kritis Dan Penalaran Matematis Siswa Melalui Model Brain Based Learning. Jurnal Cakrawala Pendas. Vol 3 No. 1 hal 13-22.

Nahdi, D S. (2017). Implementasi Model Pembelajaran Collaborative Problem Solvinguntuk Meningkatkan Kemampuan Representasi Matematis Siswa Sekolah Dasar. Jurnal Cakrawala Pendas. Vol 1 No. 1 hal 6-15.

Nahdi, D S. (2018). Eksperimentasi Model Problem Based Learning Dan Model Guided Discovery Learning Terhadap Kemampuan Pemecahan Masalah Matematis Ditinjau Dari Self Efficacy Siswa. Jurnal Cakrawala Pendas. Vol. 4, No. 1, Hal 50-56.

Novianti, Anita. (2013). Penerapan Model Pembelajaran Search, Solve, Create, And Share (SSCS) Untuk Meningkatkan Pemahaman Konsep Peserta Didik Kelas X IPS 1 SMA Negeri 4 Bandung. Skripsi Pendidikan Fakultas Ilmu Pendidikan Universitas Pendidikan Indonesia.

Ramdani, Yani. (2012). Pengembangan Instrumen Dan Baban Ajar Untuk Meningkatkan Kemampuan Komunikasi, Penalaran, Dan Koneksi Matematis Dalam Konsep Integral. Jurnal Pendidikan FMIPA UNISBA Vol 13 (1).

Sani, Abdullah R. (2014). Pembelajaran Saintifik Untuk Implementasi Kurikulum 2013. Jakarta : Bumi Aksara.

Sanjaya, Wina. (2009). Strategi Pembelajaran berorientasi Standar Proses Pendidikan. Jakarta: Kencana Prenada Media Grup.

Warsono dan Hariyanto. (2012). Pembelajaran Aktif. Bandung : PT. Remaja Rosdakarya. 